\title{
THE EFFECT OF PERCEIVED BENEFITS, TRUST, QUALITY, BRAND AWARENESS/ASSOCIATIONS AND BRAND LOYALTY ON INTERNET BANKING BRAND EQUITY
}

\author{
Sandra Maria Correia Loureiro \\ University Institute of Lisbon (ISCTE-IUL), Business Research Unit \\ (BRU/UNIDE) \\ Department of Marketing, Operations and General Management, $A v^{\underline{a}}$ \\ das Forças Armadas 1649-026 Lisbon, Portugal \\ sandramloureiro@netcabo.pt/sandra.loureiro@iscte.pt
}

\begin{abstract}
This research examines the interrelationships of trust, brand awareness/associations, perceived quality and brand loyalty in building Internet banking brand equity. The model was based on data from customers using online banking (customers of an international bank) using the PLS technique. The results suggest that perceived quality and brand loyalty are more important to explain the Internet banking brand equity than brand awareness/associations and trust. Interestingly, trust contributes only indirectly, through perceived quality and brand awareness/association to Internet banking brand equity. Online perceived benefits impact positively on customers' trust and online perceived risks tend to be lower when trust increases.
\end{abstract}

Keywords: Internet Banking Brand Equity, Trust, Brand Loyalty, Perceived Quality, Brand Awareness/Associations, Online Benefits

\section{INTRODUCTION}

In the last decade, the online banking service (Internet banking) has emerged as one of the most profitable e-commerce applications due to its convenience and other characteristics. This is particularly significant in the financial industry where convenience has become a very strong reason for the technology to be integrated in the banking business. The ability to subscribe to products and conduct transactions online has given a great boost to the way banks interact with their customers, process transactions, 
and make strategic decisions ${ }^{1}$. However, Internet banking adoption rates are markedly different across Europe. For example, in Northern Europe North, Norway and Finland, 70-80\% of Internet users adopt online banking, while in the United Kingdom, Austria and Germany it's 40-50\%, in Portugal and Italy it's $20-30 \%$, but in Greece and Romania (only) less than $10 \%$ of the population make use of online banking or brokerage ${ }^{2}$. According to the BASEF barometer study of Marktest ${ }^{3}$, online banking is the third most visited form of contact used by $28.9 \%$ of respondents, and the number of users has tripled between 2002 and 2010.

The European Union ${ }^{4}$ is calling for more research to improve the use of the Internet, smart phones and other technological innovation for financial dealings, which brings with it increased security (including fraud) risks, and uncertainty as to the presiding jurisdiction when seeking recourse. In an era of economic crisis, it is crucial to understand how to reduce online risks and vulnerabilities and improve the online banking brand equity.

Although consumers perceive online banking as offering a number of benefits, this kind of transition also tends to manifest some types of risks perceived by customers. In fact, Meyer ${ }^{2}$ points out that security concerns are an often-voiced impediment to online banking. So, building online trust should be an important precondition to create online brand equity. It will also be important to provide a satisfying online experience that stimulates memory-resident positive imagery of the firm ${ }^{5}$ or bank. However, previous studies do not provide sufficient empirical information as to how trust can contribute to Internet banking brand equity and how brand awareness/association, perceived quality and brand loyalty are related to each other and contribute to Internet banking brand equity. Therefore, the aim of this study is to provide insights into the interrelationships among the antecedents (trust, brand awareness/associations, perceived quality and brand loyalty) of Internet banking brand equity and empirically test the strength of each antecedent in building Internet banking brand equity. This intention implies firstly reviewing current literature on brand equity and online trust, which represent the theoretical foundation for the hypotheses with regard to the impact of brand awareness/associations, perceived quality, brand loyalty and Internet banking trust on Internet banking brand equity. This is then followed by a presentation of the methodology applied in the research, findings and results on hypotheses testing. Finally, the study's findings, contribution, and theoretical and managerial implications are discussed. 


\section{THEORECTICAL BACKGROUND AND RESEARCH HYPOTHESES}

In literature we can find direct and indirect measures of brand equity. In the direct approach, an attempt is made to assess the value added by the brand to the product ${ }^{6,7}$. This approach is closely linked to the accepted definition of brand equity. Aaker ${ }^{8}$ defines brand equity as the sum of assets that are associated with the brand name, such as awareness, loyalty and perceived quality, as well as other proprietary assets. Similarly, Keller ${ }^{7}$ proposes a knowledge-based framework for creating brand equity based on two dimensions: brand awareness and brand image. The indirect approach focuses on the identification of the potential sources of brand equity ${ }^{7,8}$. However, Keller ${ }^{7}$ argues that the direct and indirect approaches are complementary and should be used together.

Although in all these definitions the notion that brand equity adds value to the good or service is apparent, two different research approaches can be perceived: a business perspective and a consumer perspective. It is the approach based on the consumer perspective that is the particular concern of this paper. According to Myers ${ }^{9}$, the consumer perspective can be divided again into two components: one based on consumer perceptions and the other based on consumer attitudes and behaviour.

The following literature review implies that, on the basis of the objective to analyse the attitudes and behaviours of online consumers, some additional factors not inherent in the definitions provided to date, that is perceived benefits, perceived quality, brand awareness/associations, trust, risks and brand preference should also be considered. The present study's conceptual model is shown in Figure 1.

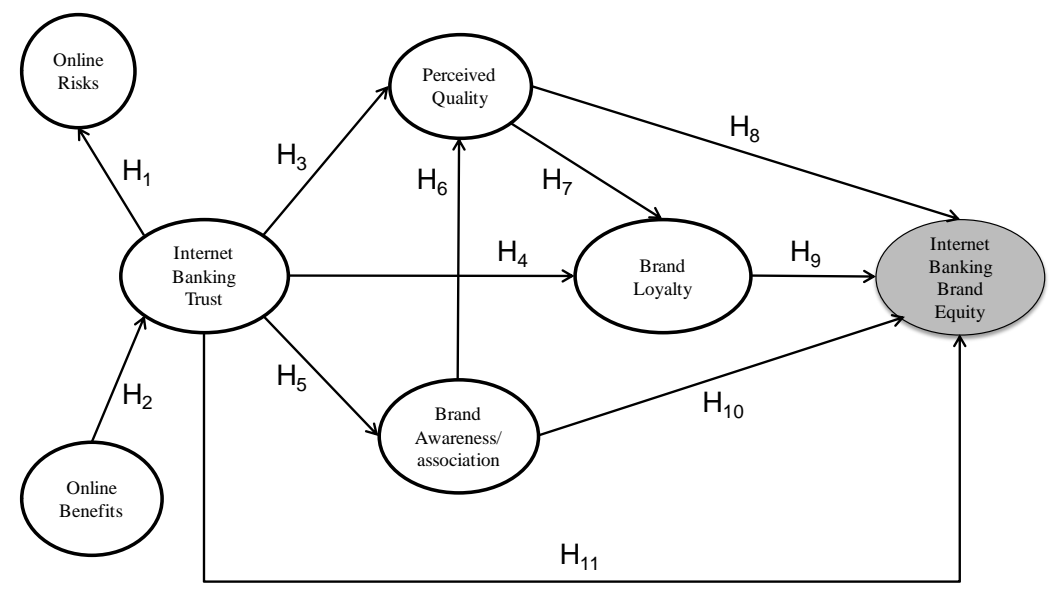

Figure 1. Conceptual model proposed 


\subsection{Online Trust, Perceived Risks and Perceived Benefits}

The concept of trust emerges in the sense of acceptance of consumers' vulnerability stemming from the positive impressions of a website and the implicit expectations that it will deliver on a promise ${ }^{10}$. Trust has been studied primarily in the context of relationship marketing ${ }^{11,12,13}$. Morgan and $\operatorname{Hunt}^{11}$ (p.23) conceptualize trust as happening "when one part has confidence in an exchange partner's reliability and integrity."

In their seminal work, Ambler ${ }^{14}$ presents trust as an affective (not a cognitive), analytical construct, which can even be a proxy for brand equity. Similarly, Rousseau et al. ${ }^{15}$ (p.395) define trust as a "psychological state comprising the intention to accept vulnerability based on positive expectations of the intentions or behaviors of another." Later, Bart et al. ${ }^{10}$ adopted this last definition to the context of online trust. Yoon ${ }^{5}$ alludes to the existence of six factors (security assurance, brand, search, fulfillment, presentation and technology) that formally represent the essence of online trust, which, over time, reflects on personality attributes such as dependability, reliability and honesty. Therefore, being related to online trust, perceived risks and benefits are key points to determine the course of action ${ }^{16}$ regarding instances such as online purchases and Internet banking use.

Consumers tend to have high levels of risk perceptions concerning Internet shopping ${ }^{17}$. These perceptions can be divided into three types of risk $^{18,19}$ : (1) product performance, in the sense that a person may not obtain the product intended; (2) financial risk, meaning a potential net loss of money ${ }^{20}$; and (3) time/convenience risk, incurred during online transactions (navigation, submission of orders and delays in receiving products). Trust is largely associated with lower levels of perceived risk and with customers' perceptions of security and privacy. Trust works as a mechanism for reducing consumers' perceived risk in Internet shopping ${ }^{21}$, customers' transaction-specific uncertainty and the number of related risks associated with the possibility that a bank might behave opportunistically ${ }^{22}$. Furthermore, it lowers the perceived risk of facing a negative outcome of a transaction by reducing information complexity ${ }^{23}$. However, the causal relational order between trust and perceived risk is not yet clarified. This research follows the works of Aldás-Manzano et al. ${ }^{24}$ and Yousafzai et al. ${ }^{25}$ and states that high levels of trust of Internet banking reduce perceived risk.

Consumers also tend to consider benefits regarding Internet shopping. Therefore, perceived benefits can be categorized into functional and non-functional forms. The first one relates to convenience, a broader range of products and lower prices in non-store shopping. Non-functional benefits are related to hedonic enjoyment in the sense of a new experience in 
shopping ${ }^{26,27}$. Moreover, perceived benefits of online banking (like ease of usage and convenience) are anticipated to build trust. On these grounds, this study suggests the following hypotheses:

H1: Trust has a negative effect on risk perceived by the e-banking consumer.

H2: Perceived benefits have a positive effect on trust.

\subsection{Brand Awareness/Associations and Perceived Quality as Mediators between Trust and Brand Loyalty}

From a consumer's perspective, brand awareness/associations seem to be of particular interest in this context. Brand awareness/associations are related to the strength of the brand node or trace in memory, as reflected by consumers' ability to identify the brand under different conditions ${ }^{7,28}$. These awareness/associations represent the favorable, strong, and unique associations in consumer "memory."

As for perceived quality, the concept has been broadly studied in the field of relationship marketing. The effect of high quality on brand loyalty is well known and is widely accepted as the basis of consumer satisfaction ${ }^{29}, 30$, $31,32,33,34,35,36$. Grönroos ${ }^{37}$ defines service quality as an overall perceived judgment. In the same vein but more specifically, Zeitham ${ }^{38}$ defines perceived service quality as the customer's assessment of the overall excellence or superiority of the service. Thus, service quality has been considered as an overall evaluation of the service that contributes to loyalty towards a service, good or brand, when positively evaluated.

Brand loyalty has been defined as "a deeply held commitment to rebuy or repatronize a preferred product/service consistently in the future, thereby causing repetitive same-brand or same-brand set purchasing, despite the fact that situational influences and marketing efforts have the potential to cause switching behavior" ${ }^{39}$ (p.34). Chaudhuri ${ }^{40}$ has proposed that brand loyalty is the preference of a customer for a single brand, or preference to buy a particular brand name in a product class regularly. In this way, this study regards brand loyalty as being loyal to the bank brand.

Yoon $^{5}$ proposes that consumer awareness is a mediating variable on web-site trust and satisfaction and suggests that online trust can exercise a positive effect on website awareness. In this research, online trust is interrelated with loyalty and will positively influence the perceived quality ${ }^{22}$, $24,25,35,41$. In addition, brand awareness/association plays an important role in consumers' evaluations ${ }^{42}$, such as quality evaluation. Accordingly, the following hypotheses are proposed: 
H3: Trust has a positive effect on perceived quality.

H4: Trust has a positive effect on brand loyalty.

H5: Trust has a positive effect on brand awareness/association.

H6: Brand awareness/association has a positive effect on perceived quality.

H7: Perceived quality has a positive effect on brand loyalty.

\subsection{Antecedents of Brand Equity}

Brand equity can be considered to be the difference between overall brand preference and multi-attributed preference based on objectively measured attribute levels ${ }^{43}$ and as an overall quality and choice intention ${ }^{44}$. Yoo, Donthu, and Lee ${ }^{45}$ demonstrated that the level of brand equity is positively related to the extent to which brand quality, brand loyalty, brand associations and awareness are evident in the product (e.g., athlete's shoes, camera film, and color television sets). High perceived quality would drive a consumer to choose the brand rather than other competing brands. Therefore, the more brand quality is perceived by consumers, the more brand equity will increase. Brand loyalty makes consumers purchase a brand routinely and resist switching to another brand. Hence, the more consumers are loyal to the brand, the more brand equity will increase. Brand associations, which result in high brand awareness, are positively related to brand equity because they can be a signal of quality and commitment and help a buyer to consider the brand at the point of purchase, which leads to a favorable behavior towards the brand. Yoo and Donthu ${ }^{46}$ developed a multidimensional consumer-based brand equity scale. They also suggested that a potential causal order among the dimensions of brand equity might exist. Thus, their hierarchy of effects model suggests that brand awareness and associations precede perceived quality and that perceived quality precedes brand loyalty ${ }^{46}$ (p.12).

Several researchers pointed out that high brand equity is associated with high brand preference and loyalty ${ }^{47,48,49}$. Accordingly, Chang and Liu's ${ }^{50}$ model empirically supports the claim that brands with higher levels of brand equity generate higher levels of customer brand preference. In turn, higher customer brand preference is associated with a greater willingness to continue using the service brand. Similarly, Miller, Foust and Kilic ${ }^{51}$ claim that long-established brands reflect a high degree of brand equity. Concomitantly, customers' online trust will positively affect brand equity ${ }^{52}$. Hence, this study offers the following hypotheses: 
H8: Perceived quality has a positive effect on Internet banking brand equity.

H9: Brand loyalty has a positive effect on Internet banking brand equity.

H10: Brand awareness/association has a positive effect on Internet banking brand equity.

H11: Trust has a positive effect on Internet banking brand equity.

\section{RESEARCH METHOD}

\subsection{Data Collection}

First, the research focus and scope were identified, and relevant studies were collected for review. After developing the questionnaire, a pilot test was conducted with ten Internet banking customers. This test personally conducted with customers who are familiar with Internet banking helped to purify the scale items of the questionnaire and find out if the items were well understood. Therefore, we assessed the face and content validity of the operational measures and ensured that customers understood the study's instructions, questions and response scales in the ways intended. As an additional procedure to reduce method biases, in the header of the questionnaire we assured respondents that there were no right or wrong answers and that participants (banking users) should answer questions as honestly as possible ${ }^{53}$.

In order to collect online banking users' information, we first required the permission of a large international and private bank operating in Portugal to express our need for the information for research purposes. After that, the private bank helped to email letters of invitation to its users with a message explaining the need to understand their (the users') experience in using online banking services. The letter of invitation was also linked to a website where users could fill out an online questionnaire. In order to reduce the possibility of a respondent participating in the survey more than once, the bank that participated in this study requested that each respondent provide his/her mobile phone number. Later, multiple answers from the same participant were eliminated whenever the telephone numbers were duplicated. The private data (e.g., telephone number) was kept in the bank only.

The online survey, which yielded 231 responses, was conducted over the course of a month (July 2011), with incomplete responses and missing values deleted, resulting in a sample size of 210 users for an overall response rate of almost $60 \%$. As Table 1 shows, the profile of the respondents corresponded to major participation by the male gender $(67.6 \%)$. The majority of respondents $(71.4 \%)$ were between 26 to 45 years old. We gathered questionnaires from almost all the regions in Portugal, but mostly 
from Lisbon and Oporto. As for education levels, $45.7 \%$ of respondents were graduate school and $12.4 \%$ were undergraduate (individuals who have not finished their degree, bachelor).

Table 1. Survey customer profile

\begin{tabular}{lll}
\hline Gender & Age & Education \\
\hline Male: $67.6 \%$ & $18-25: 7.1 \%$ & Less than 9 years: $1.0 \%$ \\
Female: $32.4 \%$ & $26-35: 40.0 \%$ & 9 years: $8.5 \%$ \\
& $36-45: 31.4 \%$ & High school: $19.5 \%$ \\
& $46-55: 12.9 \%$ & $\begin{array}{l}\text { Undergraduate (individuals } \\
\text { who have not finished their } \\
\text { degree, bachelor): } 12.4 \%\end{array}$ \\
& & $\begin{array}{l}\text { Graduate (individuals who } \\
\text { completed their degree, } \\
\text { bachelor): } 45.7 \%\end{array}$ \\
& $56-65: 5.7 \%$ & Master or PhD Degree: $12.9 \%$ \\
& & \\
\hline
\end{tabular}

\subsection{Variables and Measurements}

Brand awareness/associations, perceived quality, brand loyalty and Internet banking brand equity were operationalized based on Yoo and Donthu $^{45,50}$, Zeithaml et al. ${ }^{32}$ and Keller ${ }^{7}{ }^{54}$. Internet banking trust was measured by using four items adapted from Bart et al. ${ }^{10}$. Online benefits and online risks were adapted from Forsythe et al. ${ }^{17}$. Each statement of the questionnaire was recorded on a 5-point Likert scale $(1=$ strongly disagree, $5=$ strongly agree). The instrument was drawn up in English, translated into Portuguese and then back translated into English using a dual focus method in order to communicate similar information to those devised in English (adapted from the literature) ${ }^{55}$.

\subsection{Data Analysis}

To analyze our data, we used partial least squares (PLS), which employs a component-based approach for purposes of estimation ${ }^{56}$ and can readily handle formative factors ${ }^{57}$. In general, PLS is better suited for explaining complex relationships than it is for simple relationships because it avoids two problems: inadmissible solutions and factor indeterminacy ${ }^{58}$. According to Hsu et al. ${ }^{59}$, PLS serves a better prediction when sample size is not large and the model is complex. On the strength of these considerations we chose the PLS approach. 
The PLS model is analyzed and interpreted in two stages. First, the adequacy of the measures is assessed by evaluating the reliability of the individual measures and the discriminant validity of the constructs ${ }^{60}$. Then, the structural model is appraised. Composite reliability is used to analyze the reliability of the constructs since it has been regarded to be a more exact measurement than the Cronbach's alpha ${ }^{61}$. To determinate convergent validity, we compute the average variance of variables extracted by constructs (AVE), which should be at least 0.5, and to assess discriminant validity we follow the rule that the square root of AVE should be greater than the correlation between the construct and other constructs in the model $^{61}$. Bootstrap (a nonparametric approach) is used to estimate the precision of the PLS estimates and analyze the significance of the beta coefficients. Tenenhaus, Vinzi, Chatelin and Lauro ${ }^{62}$ proposed the geometric mean of the average communality (outer model) and the average $\mathrm{R}^{2}$ (inner model) (going from 0 to 1 ) as overall goodness of fit (GoF) measures for PLS.

Wetzels et al. ${ }^{63}$ point out that three different effect sizes for $\mathrm{R}^{2}$ have different acceptable GoF values. The effect size for $R^{2}\left(f^{2}\right)$ defined by Cohen and Cohen ${ }^{64}$ (p.155) is determined by $\mathrm{f}^{2}=\mathrm{R}^{2} /\left(1-\mathrm{R}^{2}\right)$. Thus, the effect sizes for $\mathrm{R}^{2}$ include the limits: small $=0.02$, medium $=0.13$, and large $=0.26$. Following GoF criteria for each effect size has been proposed: GoFsmall $\geq 0.1$, GoFmedium $\geq 0.25$ and GoFlarge $\geq 0.36^{63}$.

\section{RESULTS}

Table 2 shows that all loadings of reflective construct is equal to or above 0.722 , thus exceeding the minimum value of 0.707 , which indicates that more than $50 \%$ of the variance in the manifest variable is explained by the construct ${ }^{65}$, except for the items BA2 and T1, which were eliminated from the sample. Table 2 also indicates that all constructs are reliable since the composite reliability values exceed the threshold of 0.7 and even the strictest value of $0.8^{66}$. The measures demonstrate convergent validity since the average variance of manifest variables extracted by constructs (AVE) is at least 0.5 , indicating that more variance is explained than unexplained in the variables associated with a given construct. 
Table 2. Measurement results

\begin{tabular}{|c|c|c|c|c|}
\hline Construct & $\begin{array}{l}\text { LV } \\
\text { Mean }\end{array}$ & $\begin{array}{c}\text { Item } \\
\text { Loading }\end{array}$ & $\begin{array}{l}\text { Composite } \\
\text { Reliability }\end{array}$ & $\mathrm{AVE}^{*}$ \\
\hline Brand Awareness/Associations & 4.1 & & 0.87 & 0.69 \\
\hline $\begin{array}{l}\text { BAW1: I can recognize } \mathrm{x} \text { among } \\
\text { other competing brands }\end{array}$ & & 0.851 & & \\
\hline BAW2: I am aware of $\mathrm{x}$ & & 0.895 & & \\
\hline $\begin{array}{l}\text { BAW3: I can quickly recall the } \\
\text { symbol or logo of } x\end{array}$ & & 0.736 & & \\
\hline $\begin{array}{l}\text { BAW4: I have difficulty } \\
\text { imagining } x \text { in my mind. (r) }\end{array}$ & & a & & \\
\hline Perceived Quality & 3.6 & & 0.88 & 0.78 \\
\hline $\begin{array}{l}\text { Q1: The quality of website } \\
\text { services provided by } x \text { is } \\
\text { extremely high }\end{array}$ & & 0.903 & & \\
\hline $\begin{array}{l}\text { Q2: The visual design of website } \mathrm{x} \\
\text { has an extremely high quality }\end{array}$ & & 0.867 & & \\
\hline Brand Loyalty & 3.6 & & 1.00 & 1.00 \\
\hline $\begin{array}{l}\text { L1: I consider myself to be loyal } \\
\text { to } \mathrm{x}\end{array}$ & & 1.000 & & \\
\hline Internet Banking Trust & 3.8 & & 0.93 & 0.82 \\
\hline $\begin{array}{l}\text { T1: I have more confidence in this } \\
\text { website than other sites I have } \\
\text { visited }\end{array}$ & & $\mathrm{a}$ & & \\
\hline $\begin{array}{l}\text { T2: My overall trust in this site is } \\
\text { high }\end{array}$ & & 0.864 & & \\
\hline $\begin{array}{l}\text { T3: My overall believability of the } \\
\text { information on this site is high }\end{array}$ & & 0.939 & & \\
\hline $\begin{array}{l}\text { T4: My overall confidence in the } \\
\text { recommendations on this site is } \\
\text { high }\end{array}$ & & 0.910 & & \\
\hline
\end{tabular}


Table 2. Measurement results (Cont.)

\begin{tabular}{|c|c|c|c|c|}
\hline Construct & $\begin{array}{l}\text { LV } \\
\text { Mean }\end{array}$ & $\begin{array}{c}\text { Item } \\
\text { Loading }\end{array}$ & $\begin{array}{l}\text { Composite } \\
\text { Reliability }\end{array}$ & AVE* \\
\hline Internet Banking Brand Equity & 3.4 & & 0.93 & 0.81 \\
\hline $\begin{array}{l}\text { BE1: I sign products in website } x \\
\text { instead of any other bank, even if } \\
\text { they are identical }\end{array}$ & & 0.876 & & \\
\hline $\begin{array}{l}\text { BE2: Even if another bank has the } \\
\text { same characteristics as } x \text {, I prefer to } \\
\text { sign products in website } x\end{array}$ & & 0.925 & & \\
\hline $\begin{array}{l}\text { BE3: If there is a bank with an } \\
\text { online service as good as } x \text {, then I } \\
\text { still prefer } x\end{array}$ & & 0.899 & & \\
\hline Online Benefits & 4.1 & & 0.90 & 0.70 \\
\hline B1: I can sign products at home & & 0.876 & & \\
\hline $\begin{array}{l}\text { B2: I can sign products whenever I } \\
\text { want }\end{array}$ & & 0.843 & & \\
\hline $\begin{array}{l}\text { B3: I can sign products online } \\
\text { without going to the agency }\end{array}$ & & 0.830 & & \\
\hline B4: I sign products easily & & 0.796 & & \\
\hline Online Risks & 2.4 & & 0.90 & 0.60 \\
\hline $\begin{array}{l}\text { R1: I feel a lack of confidence in } \\
\text { the website }\end{array}$ & & 0.769 & & \\
\hline $\begin{array}{l}\text { R2: I may not get the product I } \\
\text { want }\end{array}$ & & 0.769 & & \\
\hline $\begin{array}{l}\text { R3: I may sign something by } \\
\text { accident }\end{array}$ & & 0.722 & & \\
\hline $\begin{array}{l}\text { R4: There may be some technical } \\
\text { failure }\end{array}$ & & 0.782 & & \\
\hline $\begin{array}{l}\text { R5: It's difficult to get information } \\
\text { about the product }\end{array}$ & & 0.788 & & \\
\hline $\begin{array}{l}\text { R6: It's too difficult to sign } \\
\text { products }\end{array}$ & & 0.780 & & \\
\hline
\end{tabular}

As we can see in Table 3, the measures demonstrate convergent validity and discriminant validity, according to the criteria that the square root of AVE should be greater than the correlation between the construct and other constructs in the model ${ }^{61}$. 
Table 3. Discriminant validity: Square root of AVE and correlations of constructs

\begin{tabular}{lccccccc}
\hline & \multicolumn{8}{c}{ Correlations of Constructs } \\
Construct & 1 & 2 & 3 & 4 & 5 & 6 & 7 \\
\hline AVE $^{1 / 2}$ & 0.83 & 0.84 & 0.90 & 1.00 & 0.88 & 0.78 & 0.90 \\
1. Brand & 1.00 & 0.37 & 0.59 & 0.50 & 0.67 & -0.19 & 0.51 \\
Awareness/Associations & 0.37 & 1.00 & 0.37 & 0.20 & 0.51 & -0.37 & 0.56 \\
2. Online Benefits & 0.59 & 0.37 & 1.00 & 0.71 & 0.71 & -0.24 & 0.52 \\
3. Internet Banking & & & & & & \\
Brand Equity & 0.50 & 0.20 & 0.71 & 1.00 & 0.63 & -0.14 & 0.46 \\
4. Brand Loyalty & 0.67 & 0.51 & 0.71 & 0.63 & 1.00 & -0.27 & 0.68 \\
5. Perceived Quality & -0.19 & -0.37 & -0.24 & -0.14 & -0.27 & 1.00 & -0.46 \\
6. Online Risks & 0.51 & 0.56 & 0.52 & 0.46 & 0.68 & -0.46 & 1.00 \\
7. Internet Banking Trust
\end{tabular}

The correlation matrix (Table 3) did not indicate any exceptionally correlated variables (the highest correlation among principal constructs is $r$ $=0.71$ ) ; evidence of common method bias usually results in very high correlations $(r>0.90)^{67}$. Furthermore, "it should be noted that by using the PLS algorithm under a reflective mode for all constructs, we eliminate any concerns of colinearity within blocks of variables used to represent underlying constructs" ${ }^{\prime 68}$ (p. 40).

The structural results are presented in Figure 2. Eight path coefficients are found to be significant at the 0.001 or 0.05 level, and three are not significant. All coefficients have the sign anticipated, even the negative coefficient between online risks and trust. As mentioned above, bootstrap (a nonparametric approach) is used to estimate the precision of the PLS estimates and analyze the significance of the beta coefficients. Accordingly, 500 sample sets were created in order to obtain 500 estimates for each parameter in the PLS model. Each sample was obtained by sampling with replacement to the original data set ${ }^{61,69}$. The GoF and $\mathrm{f}^{2}$ reveal a good fit. 


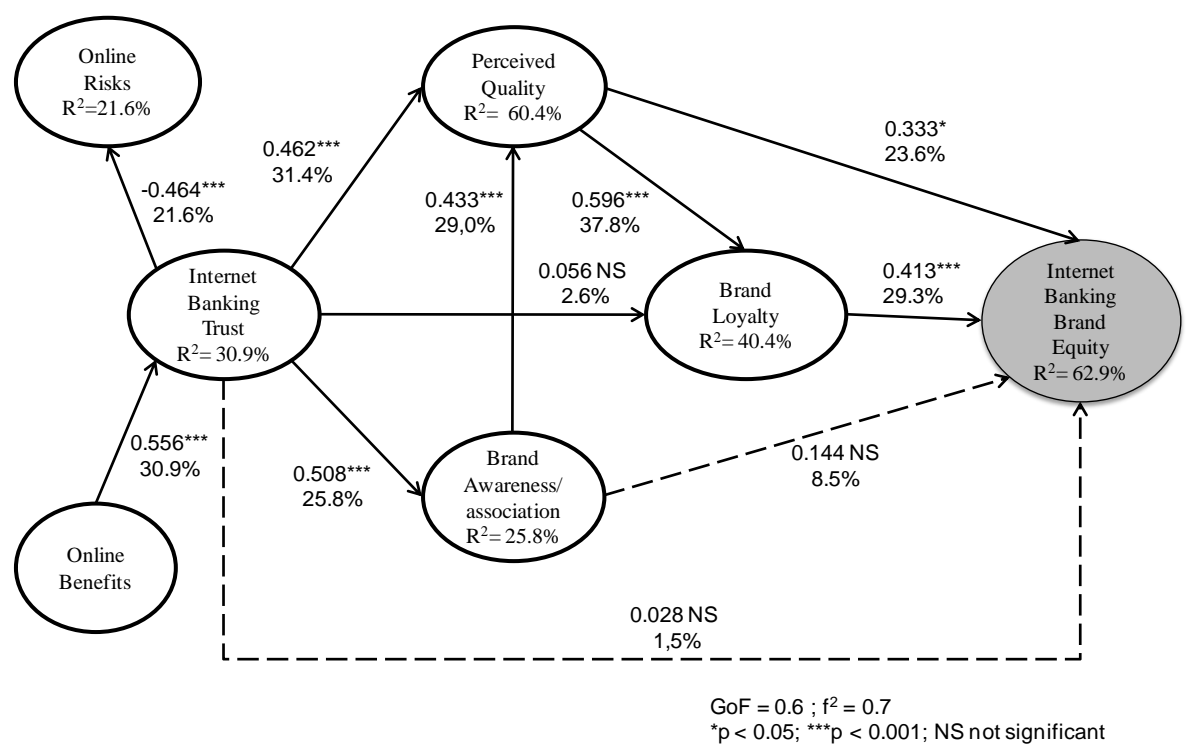

Figure 2. Structural results

The results show that brand loyalty is the most important predictor of Internet banking brand equity. However, perceived quality significantly impacts Internet banking brand equity. The multiplication of the Pearson' $s$ correlation value for the path coefficient value of each of the two constructs reveals that $53 \%$ of the Internet banking brand equity variability is explained by brand loyalty and perceived quality. Surprisingly, brand awareness/associations and trust do not tend to significantly contribute to Internet banking brand equity. The variable online benefits are good predictors of trust, which is a good predictor of brand awareness/associations, perceived quality and online risks.

\section{DISCUSSION AND IMPLICATIONS}

This study is an attempt to provide insights into antecedents of brand equity that were previously studied in the offline markets, providing an online context. So, we considered and validated new aspects that were deemed to be important in Internet banking.

The results show that Internet banking brand equity significantly depends on brand loyalty and perceived quality. But the strength of the relationship between Internet banking trust and Internet banking brand equity is not significant, and the effect of Internet banking trust on brand loyalty does not occur, which contradicts the expectations created by the study of Delgado-Ballester and Hernández-Espallardo ${ }^{51}$. They claim that internal brand-generated factors (e.g., its website) as well as external third-party factors (e.g., alliance with a well-known brand) "exert a positive 
influence on brand trust and consequently on its equity and consumers' willingness to behave in a favorable manner" ${ }^{31}$ (p.970). This implies that the influence of trust on brand equity has to be differentiated as to online and offline conditions. This might also reflect the fact that online trust has not yet been successfully created.

The relationship between the Internet banking trust and online risks has, as expected, a significant but reverse effect, which corroborates the findings provided by Yousafzai, Pallister and Foxall ${ }^{24}$ and Aldás-Manzano et al. ${ }^{23}$.

Although it is necessary to develop other empirical studies within the Internet banking context, this study does underline the importance of perceived quality and brand loyalty in building Internet banking brand equity. However, the relationship between Internet brand equity and brand loyalty could have a dual effect. Being loyal to the bank's brand is important to achieve good Internet banking brand equity, but the reverse could also be true, like a vicious cycle of mutual reinforcement and support. Trust helps reduce the online perceived risk and helps improve the perceived quality. In this sense, trust only indirectly affects Internet banking brand equity through brand awareness/associations, perceived quality and brand loyalty.

From the theoretical point of view, the findings show that online benefits contribute positively to trust. Trust, in turn, is an important indirect antecedent to building Internet banking brand equity. Customers who have confidence in their Internet banking tend to reinforce their positive awareness and associations with their bank brand and to more favorably evaluate the quality of the bank website service. Brand awareness/associations and perceived quality act as mediators between trust and brand loyalty. Internet banking brand loyalty, in turn, contributes directly and jointly with perceived quality for Internet banking brand equity.

From the managerial standpoint, the online banking website managers should be aware of how the website is visually designed and presented, both in terms of quality of design and ease of use through the introduction of more mechanisms of risk reduction. These elements reinforce the trust and perceived quality, and the latter helps to increase online brand equity directly and indirectly by enhancing brand loyalty.

Banks should develop a marketing communication that invests in and shows the commitment they have to not misleading the consumer, enhancing the identity created as a corporation for the online context. An image of quality and trust in the consumer's mind, linked to corporate and banking services offline, should be created in the mind of the consumer for services online. In other words, if the bank is trustworthy and provides a reliable service offline, then under the same corporate brand it is expected to 
maintain that same reputation, at least in terms of trust in the online service. As Khare $^{70}$ points out in the case of online banking in India, we consider that in Portugal, involvement of the service staff would be instrumental in building trust with the customers and helping them achieve improved access to and utilization of online services.

Further directions for future studies may involve an exploratory study in other commercial online contexts. Other types of variables could be examined in this concept to support these findings. Future studies could also gain greater/improved consistency by gathering a larger sample covering different cultural contexts of different countries.

\section{REFERENCES}

[1] K.M. Bakare, Technology risk: Preparing for the next move. Community Banker, 17(9), p26-27, 2008.

[2] T. Meyer, Online banking. What we learn from differences in Europe. In A. Stobbe (Ed.), E-banking snapshot 16, deutsche bank research, frankfurt am main. Retrieved on February 24, 2011, from http://www.dbresearch.de/PROD/DBR_INTERNET_DE-PROD/PROD 0000000000196129.pdf.

[3] Marktest, BASEF barometer. Retrieved on February 24, 2011, from http://www.marktest.com/wap/a/n/id 171b.aspx.

[4] European Union, Commission staff working document - European financial stability and integration report 2011 (Brussels, 13.4.2012). Retrieved on April 10, 2012, from http://ec.europa.eu/internal_market/economic_analysis/docs/financial_i ntegration_reports/20120426-efsir_en.pdf.

[5] S.-J. Yoon, The antecedents and consequences of trust in online purchase decisions. Journal of Interactive Marketing, 16(2), p47-63, 2002. http://dx.doi.org/10.1002/dir.10008.

[6] P. Farquhar, Managing brand equity. Marketing Research, 1(3), p24-33, 1989.

[7] K. Keller, Conceptualizing, measuring, and managing customer-based brand equity. Journal of Marketing, 57(1), p1-22, 1993. http://dx.doi.org/10.2307/1252054.

[8] D. Aaker, Managing brand equity: Capitalizing on the value of a brand name. New York: The Free Press, 1991.

[9] C. Myers, Managing brand equity: A look at the impact of attributes. Journal of product and Brand Management, 12(1), p39-51, 2003. http://dx.doi.org/10.1108/10610420310463126.

[10] Y. Bart, V. Shankar, F. Sultan, and G. Urban, Are the drivers and the role of online trust the same for all web sites and consumers? A large-scale exploratory empirical study. Journal of Marketing, 69(4), 
p133-152, 2005. http://dx.doi.org/10.1509/jmkg.2005.69.4.133.

[11] R.M. Morgan, and S.D. Hunt, The commitment-trust theory of relationship marketing. Journal of Marketing, 58(3), p20-38, 1994. http://dx.doi.org/10.2307/1252308.

[12] P.M. Doney, and J.P. Cannon, An examination of the nature of trust in buyer-seller relationships. Journal of Marketing, 61(2), p35-51, 1997. http://dx.doi.org/10.2307/1251829.

[13] S. Ganesan, and R. Hess, Dimensions and levels of trust: Implications for commitment to a relationship. Marketing Letters, 8(4), p439-448, 1997.

[14] T. Ambler, How much of brand equity is explained by trust? Management Decision, 35(4), p283-292, 1997. http://dx.doi.org/10.1108/00251749710169666.

[15] D.M. Rousseau, S.B. Bitkin, R.S. Burt, and C. Camerer, Not so different after all: A cross-discipline view of trust. Academy of Management Review, 23(3), p393-404, 1998. http://dx.doi.org/10.5465/AMR.1998.926617.

[16] R. Cooper, and R. Slagmulder, Developing meaningful profitability maps cascading cost/benefit tradeoffs. Management Accounting, 80(6), p16-18, 1998.

[17] S. Forsythe, Ch. Liu, D, Shannon, and L.C. Gardner, Development of a scale to measure the perceived benefits and risks of online shopping. Journal of Interactive Marketing, 20(2), p55-75, 2006. http://dx.doi.org/10.1002/dir.20061.

[18] S. Forsythe, T. Petee, and J.-O. Kim, Modeling Consumer Behavior in On-Line Environments: Scale Development (Annual Reports). National Textile Center, PA, Spring House, 2002.

[19] S. Forsythe, and B. Shi, Consumer patronage and risk perceptions in internet shopping. Journal of Business Research, 56(11), p867-875, 2003. http://dx.doi.org/10.1016/S0148-2963(01)00273-9.

[20] S. Jarvenpaa, and P. Todd, Consumer reactions to electronic shopping on the World Wide Web. International Journal of Electronic Commerce, 1(2), p59-88, 1997.

[21] C. Derbaix, Perceived risk and risk relievers: An empirical investigation. Journal of Economic Psychology, 3(1), p19-38, 1993. http://dx.doi.org/10.1016/0167-4870(83)90056-9.

[22] S. Yousafzai, J. Pallister, and G. Foxall, A proposed model of e-trust for electronic banking. Technovation, 23(11), p847-860, 2003. http://dx.doi.org/10.1016/S0166-4972(03)00130-5.

[23] R. Mayer, J. Davis, and F. Schoorman, An integrative model of organizational trust. Academy of Management Review, 20(3), p709-734, 1995. http://dx.doi.org/10.2307/258792. 
[24] J. Aldás-Manzano, C. Lassala-Navarré, C. Ruiz-Mafé, and S. Sanz-Blas, Key drivers of internet banking services use. Online Information Review, 33(4), p672-695, 2009. http://dx.doi.org/10.1108/14684520910985675.

[25] S. Yousafzai, J. Pallister, and G. Foxall, Multi-dimensional role of trust in Internet banking adoption. The Service Industries Journal, 29(5), p591-605, 2009. http://dx.doi.org/10.1080/02642060902719958.

[26] B.J. Babin, W.R. Darden, and M. Griffin, Work and/or fun: Measuring hedonic and utilitarian shopping value. Journal of Consumer Research, 20(4), p644-656, 1994. http://dx.doi.org/10.1086/209376.

[27] R.R. Dholakia, Going shopping: Key determinants of shopping behaviors and motivations. International Journal of Retail and Distribution Management, 27(4), p154-165, 1999. http://dx.doi.org/10.1108/09590559910268499.

[28] J.R. Rossiter, and L. Percy, Advertising and promotion management. New York: McGraw-Hill Book Company, 1987.

[29] R.L. Oliver, Measurement and evaluation of satisfaction processes in retail settings. Journal of Retailing, 57(31), p25-48, 1981.

[30] M.J. Bitner, Evaluating service encounters: The effects of physical surroundings and employee responses. Journal of Marketing, 54(4), p69-82, 1990. http://dx.doi.org/10.2307/1251871.

[31] C. Fornell, A national customer satisfaction barometer: The Swedish experience. Journal of Marketing, 56(1), p6-21, 1992. http://dx.doi.org/10.2307/1252129.

[32] V. Zeithaml, L. Berry, and A. Parasuraman, The behavioral consequences of service quality. Journal of Marketing, 60(2), p31-46, 1996. http://dx.doi.org/10.2307/1251929.

[33] J.J. Cronin, M.K. Brady, and G.T. Hult, Assessing the effects of quality, value, and customer satisfaction on consumer behavioural intentions in service environments. Journal of Retailing, 76(2), p193-218, 2000. http://dx.doi.org/10.1016/S0022-4359(00)00028-2.

[34] M. Al-Hawari, The effect of automated service quality on bank financial performance and the mediating role of customer retention. Journal of Financial Services Marketing, 10(3), p228-243, 2005. http://dx.doi.org/10.1057/palgrave.fsm.4770189.

[35] S.M.C. Loureiro, and F.J.M. González, The importance of quality, satisfaction, trust and image in relation to rural tourism loyalty. Journal of Travel and Tourism Marketing, 25(2), p117-136, 2008. http://dx.doi.org/10.1080/10548400802402321.

[36] S.M.C. Loureiro, and E. Kastenholz, Corporate reputation, satisfaction, delight, and loyalty towards rural lodging units. International Journal of Hospitality Management, 30(3), p575-583, 2011. http://dx.doi.org/10.1016/j.ijhm.2010.10.007. 
[37] C. Grönroos, A service quality model and its marketing implications. European Journal of Marketing, 18(4), p36-44, 1984. http://dx.doi.org/10.1108/EUM0000000004784.

[38] V.A. Zeithaml, Consumer perceptions of price, quality, and value: A means-end model and synthesis of evidence. Journal of Marketing, 52(3), p2-22, 1988. http://dx.doi.org/10.2307/1251446.

[39] R.L. Oliver, Whence Consumer Loyalty? Journal of Marketing, 63(3), p33-44, 1999. http://dx.doi.org/10.2307/1252099.

[40] A. Chaudhuri, Consumption emotion and perceived risk: A macro analytic approach. Journal of Business Research, 39(2), p81-92, 1997. http://dx.doi.org/10.1016/S0148-2963(96)00144-0.

[41] K.H. Kim, K.S. Kim, D.Y. Kim, J.H. Kim, and S.H. Kang, Brand equity in hospital marketing. Journal of Business Research, 61(1), p75-82, 2008. http://dx.doi.org/10.1016/j.jbusres.2006.05.010.

[42] S.M. Osselaer, and C. Janiszewski, Two ways of learning brand associations. Journal of Consumer Research, 28(2), p202-223, 2001. http://dx.doi.org/10.1086/322898.

[43] C.S. Park, and V. Srinivasan, A survey-based method for measuring and understanding brand equity and its extendibility. Journal of Marketing Research, 31(2), p271-288, 1994. http://dx.doi.org/10.2307/3152199.

[44] M.K. Agarwal, and V.R. Rao, An empirical comparison of consumer based measures of brand equity. Marketing letters, 7(3), p237-247, 1996. http://dx.doi.org/10.1007/BF00435740.

[45] B. Yoo, N. Donthu, and S. Lee, An examination of selected marketing mix elements and brand equity. Journal of the Academy of Marketing Science, 28(2), p195-211, 2000. http://dx.doi.org/10.1177/0092070300282002.

[46] B. Yoo, and N. Donthu, Developing and validating a multidimensioanl consumer-based brand equity scale. Journal of Business Research, 52(1), p1-14, 2001. http://dx.doi.org/10.1016/S0148-2963(99)00098-3.

[47] C.J. Cobb-Walgren, C.A. Ruble, and N. Donthu, Brand equity, brand preference, and purchase intention. Journal of Advertising, 24(3), p25-40, 1995. http://dx.doi.org/10.1080/00913367.1995.10673481.

[48] J.F. Devlin, A.L. Gwynne, and C. Ennew, Antecedents of service expectations. The Services Industries Journal, 22(4), p117-131, 2002. http://dx.doi.org/10.1080/714005102.

[49] L. de Chernatony, F.J. Harris, and G. Christodoulides, Developing a brand performance measure for financial services brands. The Service Industries Journal, 24(2), p15-33, 2004. http://dx.doi.org/10.1080/02642060412331301232.

[50] H.H. Chang, and Y.M. Liu, The impact of brand equity on brand preference and purchase intentions in the service industries. The Service Industries Journal, 29(12), p1687-1706, 2009. 
http://dx.doi.org/10.1080/02642060902793557.

[51] D.W. Miller, J.E. Foust, and O. Kilic, An analysis of financial services brand marks. Journal of Financial Services Marketing, 11(3), p257-267, 2007. http://dx.doi.org/10.1057/palgrave.fsm.4760051.

[52] E. Delgado-Ballester, and M. Hernández-Espallardo, Building online brands through brand alliances in internet. European Journal of Marketing, 42(9/10), p954-976, 2008. http://dx.doi.org/10.1108/03090560810891091.

[53] P.M. Podsakoff, S.B. MacKenzie, J.-Y. Lee, and N.P. Podsakoff, Common method biases in behavioral research: A critical review of the literature and recommended remedies. Journal of Applied Psychology, 88(5), p879-903, 2003. http://dx.doi.org/10.1037/0021-9010.88.5.879.

[54] K. Keller, Brand synthesis: The multidimensionality of brand knowledge. Journal of Consumer Research, 29(4), p595-600, 2003. http://dx.doi.org/10.1086/346254.

[55] S. Erkut, O. Alarcón, C. Coll, L. Tropp, and H.A.V. Garcia, The dual-focus approach to creating bilingual measures. Journal of Cross-Cultural Psychology, 30(2), p206-218, 1999. http://dx.doi.org/10.1177/0022022199030002004.

[56] J.B. Lohmoller, The PLS program system: Latent variables path analysis with partial least squares estimation. Multivariate Behavioral Research, $23 \quad$ (1), 1989. http://dx.doi.org/10.1207/s15327906mbr2301_7.

[57] W.W. Chin, B.L. Marcolin, and P.R. Newsted, A partial least squares latent variable modeling approach for measuring interaction effects: Results from a Monte Carlo simulation study and an electronic mail adoption study. Information Systems Research, 14(2), p189-217, 2003. http://dx.doi.org/10.1287/isre.14.2.189.16018.

[58] C. Fornell, and F.L. Bookstein, Two structural equation models: LISREL and PLS applied to consumer exit-voice theory. Journal of Marketing Research, 19(4), p440-452, 1982. http://dx.doi.org/10.2307/3151718.

[59] S.-H. Hsu, W.-H. Chen, and M.-J. Hsieh, Robustness testing PLS, LISREAL, EQS, and ANN-based SEM for measuring customer satisfaction. Total Quality Management, 17(3), p335-371, 2006. http://dx.doi.org/10.1080/14783360500451465.

[60] J. Hulland, Use of partial least squares (PLS) in strategic management research: A review of four recent studies. Strategic Management Journal, 20(2), p195-204, 1999. http://dx.doi.org/10.1002/(SICI)1097-0266(199902)20:2<195::AID-S MJ13>3.0.CO;2-7.

[61] C. Fornell, and D.F. Larcker, Evaluating structural models with unobservables variables and measurement error. Journal of Marketing 
Research, 18 (1), p39-50, 1981. http://dx.doi.org/10.2307/3151312.

[62] M. Tenenhaus, V.E. Vinzi, Y.-M. Chatelin, and C. Lauro, PLS path modeling. Computational Statistics \& Data Analysis, 48(1), p159-205, 2005. http://dx.doi.org/10.1016/j.csda.2004.03.005.

[63] M. Wetzels, G. Odekerken-Schröder, and C. Van Oppen, Using PLS path modeling for assessing hierarchical construct models: Guidelines and empirical illustration. MIS Quarterly, 33(1), p177-195, 2009.

[64] J. Cohen, and P. Cohen, Applied multiple regression/correlation analysis for the behavioral sciences $\left(2^{\text {nd }}\right.$ ed.). Hillsdale, NJ: Lawrence Erlbaum Associates, 1983.

[65] E.G. Carmines, and R.A. Zeller, Reliability and validity assessment. London: Ed. Sage Publications, Inc, 1979.

[66] J.C. Nunnally, Psychometric theory. New York: McGraw-Hill, 1978.

[67] R.P. Bagozzi, Y. Yi, and L.W. Phillips, Assessing construct validity in organizational research. Administrative Science Quarterly, 36(3), p421-458, 1991. http://dx.doi.org/10.2307/2393203.

[68] W.W. Chin, B.L. Marcolin, and P.R. Newsted, A partial least squares latent variable modeling approach for measuring interaction effects: Results from a Monte Carlo simulation study and voice mail emotion/adoption study. In J. I. DeGross, S. Jarvenpaa, and A. Srinivasan (Eds.), Proceedings of the $17^{\text {th }}$ International Conference on Information Systems (p21-41). Cleveland, Ohio, USA: Association for Information systems, 1996.

[69] W.W. Chin, The partial least squares approach to structural equation modeling. In G.A. Marcoulides (Ed.), Modern methods for business research (p295-336). Mahwah, New Jersey: Lawrence Erlbaum Associates Publisher, 1998.

[70] A. Khare, Online banking in India: An approach to establish CRM. Journal of Financial Services Marketing, 15(2), p176-188, 2010. http://dx.doi.org/10.1057/fsm.2010.13. 